$12: 51$

<原 著 $>$

急性期脳血管障害に括ける血奨バゾプレッシン動態の検討

渡辺 誠悦

要旨：急性期脳血管障害（CVD）において, 起立前後の血浆 arginine vasopressin (AVP) を測定し, 圧受容器求心路の機能を検討した。急性期 CVD 群 (脳出血10例, 脳梗塞17例) 27例

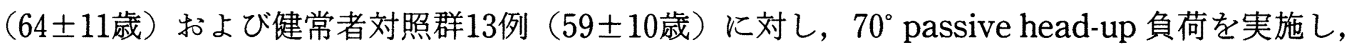
起立前・起立負荷15分後の血浆 AVP と血浆 norepinephrine（NE）を測定した。〔I〕安静仰臥 位：血浆 AVP は脳出血群, 脳梗塞群共に対照群に比し, 有意な高値を示した. 血浆 NE は脳出 血群の夕高值傾向を認め, 血浆 AVP と正相関 $(\mathrm{p}<0.05)$ を示した。〔II〕起立負荷 : 起立15分 後の血浆 AVP は脳出血群のみ有意に増加し，他の 2 群との比較でも差は有意であった。血浆 $\mathrm{NE}$ は脳出血群のみ対照群に比し増加傾向を認めた. 以上の成績は, 急性期脳出血において圧受 容器求心路が過唾に反応していることを示唆する.

Key words : cerebrovascular disorders, arginine vasopressin, autonomic nervous system, cardiovascular reflex, SIADH

(脳卒中12:51-57, 1990)

はじめに

急性期脳血管障害では自律神経系の擾乱を来すこと が知られて敃り,我々は hemodynamic な立場から, そ の自律神経障害の内容が副交感神経機能低下と交感神 経機能六進であること, 自律神経障害が脳循環 autoregulationの破綻に関与していること, 患者の予後判 定に重要であることを明らかにしてきた文 3)。これら 脳血管障害に抢ける心・血管反射は, 副交感・交感神 経遠心路あるいは圧受容器反射弓全体の機能について の成績であり, 圧受容体器求心路の機能に関する検討 ではない.

循環反射は圧受容器により常に negative feedback を受けており，脳血管障害に伴う自律神経障害の本態 を解明するためには，圧受容器の機能についても検討 する必要があると考学る。

脳血管障害患者ではしばしば水・電解質異常を経験 するが，この異常に血浆 arginine vasopressin（以下， AVP と略す)の分泌が関与し, subclinical な抗利尿木 ルモン分泌異常症候群 (SIADH) を来たす成績が報告 されている4). しかし，血浆 AVP の分泌は浸透圧刺激 以外に, 圧拉よび容量受容器からの刺激により分泌さ

埼玉医科大学神経内科
れることが知られており, 圧受容器求心路の機能を示 す指標と考えられている(5) 7).

今回, 著者は急性期脳血管障害患者に抢ける自律神 経圧受容器求心路の機能を明らかにする目的で, 血浆 AVP 動態を検討した。

\section{対象および方法}

発症 20 日以内 $(5 \pm 5.8$ 日, mean $\pm S D)$ の脳出血患者 10 例および脳梗塞患者 17 例を対象とした。年齢は $38 \sim 85$ 歳（平均年齢64.5 11.1 歳）で，性比は男性 19 例，女性 8 例である。検査時には一部の症例に意識障 害を認めたが，その程度は傾眠傾向までであった。病 单部位に関しては, 皮質下出血 2 例, 被壳出血 5 例, 視床出血 1 例, 小脳出血 2 例, 一方脳梗塞群では穿通 枝領域12例, 皮質枝領域 4 例, 小脳梗塞 1 例であった。 脳出血群では脳室穿破が 2 例に認められた。なお，こ れら患者群の中で既往に高血圧を持つものは, 脳出血 群10例中 8 例, 脳梗塞群17例中13例であった.

対照群は神経学的に異常を認めず，かつ高血圧や糖 尿病などの合併症を持たず，また喫煙習慣のない健常 者13例, 平均年齢58.7 59.7 歳である. 対照群と患者群 の年齢には有意差を認めなかった。検査は被検者ある いは家族に対し事前に説明を行い，承諾を得て実施し た。 
検査前日の夕食後から検査時まで水分・カフェイン 含有飲料・アルコール類・薬剂などの拱取を禁じた. 検査は午前 9 時から11時の間に施行した。

被検者には予め, 一側の时静脈に $22 \mathrm{G}$ テフロンカ テーテルを留置し採血に用いた。 さらに他側の上腕動 脈に $22 \mathrm{G}$ テフロンカテーテルを留置し, これに接続し たディスポーザブル血圧トランスデューサー (Spectramed Medical Products 社製 SCK-590）で全 身動脈血圧を, また, 脈拍数はデジタル心拍計（日本 光電社製 AT-600）により導出しポリグラフ上に連続 記録した. 起立試験は tilt tableを用いて30分以上の安 静仰臥位後, 15 分間の $70^{\circ}$ passive head-up tilt を行っ た. 検査は被検者の状態を常に監視しつつ慎重に実施 した。採血は肘静脈から起立直前と起立負荷15分後の 2 回行い, それぞれの静脈血について血浆 AVP, 血浆 カテコラミン, 血清浸透圧を測定した。得られた静脈 血は血清浸透圧の測定には無添加とし, 血浆 AVP お よび血浆カテコラミンの測定にはEDTA-2Na 添加後 直ちに $4{ }^{\circ} \mathrm{C} て ゙ 3,000$ 回転, 15 分間遠心分離しマイナス $80^{\circ} \mathrm{C}$ にて保存した。血浆 AVP の測定は radioimmunoassay 2 抗体法 ${ }^{8}$, 血浆カテコラミンの測定は高 速液体クロマトグラフィー法, 血清浸透圧は氷点降下 法を用いた。

推計学的検討には Student's unpaired t-test, paired t-test およびWelchの検定を用い，5\%未満を有意と した.

\section{結果}

表 1 に安静仰臥位および起立負荷15分後の血浆 $\mathrm{AVP}$, 血浆ノルェピネフリン(以下, NEと略す), 血 清浸透圧，血圧および脈拍の結果をまとめて示す。

\section{（I〕安静仰臥位}

血奨 AVP は暚出血群 $7.9 \pm 7.4 \mathrm{pg} / \mathrm{m} l$ および脳梗 塞群 $3.1 \pm 2.8 \mathrm{pg} / \mathrm{ml}$ と, 両群とも健常者群の $1.3 \pm 0.8$ $\mathrm{pg} / \mathrm{m} l$ に比し， $5 \%$ 未満の危険率で有意な上昇を認め た（表 1 , 図 1). また, 脳出血群の血浆 AVP は脳梗 塞群に対して高値傾向（p<0.1）を示した。 血清浸透 圧は脳出血群 $281 \pm 9 \mathrm{mOsm} / \mathrm{kg} \cdot \mathrm{H}_{2} \mathrm{O}$, 脳梗塞群 $285 \pm 7$ $\mathrm{mOsm} / \mathrm{kg} ・ \mathrm{H}_{2} \mathrm{O}$ および健常者群 $284 \pm 4 \mathrm{mOsm} / \mathrm{kg}$ ・ $\mathrm{H}_{2} \mathrm{O}$ であり, 3 群間に有意差を認めなかった。 本研究 では脳血管障害患者の循環血浆量の測定は行っていな いが，臨床的には明らかな脱水症状は観察されず，ま た, 血清浸透圧が $300 \mathrm{mOsm} / \mathrm{kg} \cdot \mathrm{H}_{2} \mathrm{O}$ 以上の症例は皆 無であったことから, 患者群に認められた血浆 AVP の増加に対し浸透圧因子の関与は否定的と考劣る ${ }^{9)}$. さらに, 患者群において, 臨床経過中にSIADH の発症 は 1 例も認められなかった。 なお, 血浆 NEは脳出血 群 $0.31 \pm 0.22 \mathrm{ng} / \mathrm{m} l$, 脳梗塞群 $0.23 \pm 0.16 \mathrm{ng} / \mathrm{m} l$, 健常

表 1 安静仰臥位および起立負荷に対する各パラメーターの変化量

\begin{tabular}{|c|c|c|c|}
\hline & $\begin{array}{l}\text { Cerebral } \\
\quad \text { hemorrhage }\end{array}$ & $\begin{array}{l}\text { Cerebral } \\
\quad \text { infarction }\end{array}$ & Controls \\
\hline & $\mathrm{n}=10$ & $\mathrm{n}=17$ & $\mathrm{n}=13$ \\
\hline $\begin{array}{l}\text { plasma AVP }(\mathrm{pg} / \mathrm{ml}) \\
\text { supine position }\end{array}$ & $\overbrace{7.9 \pm 7.4^{*}} \mathrm{P}$ & $3.1 \pm 2.8^{*}$ & $1.3 \pm 0.8$ \\
\hline orthostatic change & $\begin{array}{c}{ }_{7.7 \pm 6.9^{* *}} \\
\end{array}$ & $0.2 \pm 2.6$ & $0.2 \pm 1.2$ \\
\hline $\begin{array}{l}\text { serum osmolality }\left(\mathrm{mOsm} / \mathrm{kg} \cdot \mathrm{H}_{2} \mathrm{O}\right) \\
\text { supine position } \\
\text { orthostatic change }\end{array}$ & $\begin{array}{l}281 \pm 9 \\
-1 \pm 3\end{array}$ & $\begin{array}{r}285 \pm 7 \\
1 \pm 2\end{array}$ & $\begin{array}{r}284 \pm 4 \\
0 \pm 4\end{array}$ \\
\hline $\begin{array}{l}\text { plasma NE }(\mathrm{ng} / \mathrm{ml}) \\
\text { supine position } \\
\text { orthostatic change }\end{array}$ & $\begin{array}{l}0.31 \pm 0.22 \dagger \\
0.21 \pm 0.18 \dagger\end{array}$ & $\begin{array}{l}(n=16) \\
0.23 \pm 0.16 \\
0.15 \pm 0.09\end{array}$ & $\begin{array}{l}0.17 \pm 0.08 \\
0.11 \pm 0.06\end{array}$ \\
\hline $\begin{array}{l}\text { systolic } \mathrm{ABP}(\mathrm{mmHg}) \\
\text { supine position } \\
\text { orthostatic change }\end{array}$ & $\begin{array}{l}176.0 \pm 28.6^{* * *} \\
-19.0 \pm 16.7^{*}\end{array}$ & $\begin{array}{l}158.7 \pm 29.3^{* * *} \\
-12.6 \pm 15.2 \\
\end{array}$ & $\begin{array}{l}121.5 \pm 18.9 \\
-5.7 \pm 9.6 \\
\end{array}$ \\
\hline $\begin{array}{l}\text { pulse rate }(/ \mathrm{min}) \\
\text { supine position } \\
\text { orthostatic change }\end{array}$ & $\begin{array}{c}\Gamma-\mathrm{F} \\
76.9 \pm 13.8 \\
9.0 \pm 25.0\end{array}$ & $\begin{array}{l}66.1 \pm 10.4 \\
14.3 \pm 10.0\end{array}$ & $\begin{array}{l}71.3 \pm 11.4 \\
11.4 \pm 10.7\end{array}$ \\
\hline
\end{tabular}

$\dagger \mathrm{P}<0.1, \quad{ }^{*} \mathrm{P}<0.05, \quad{ }^{* *} \mathrm{P}<0.01, \quad{ }^{* * *} \mathrm{P}<0.001$ vs for controls (mean $\pm \mathrm{SD}$ ) 


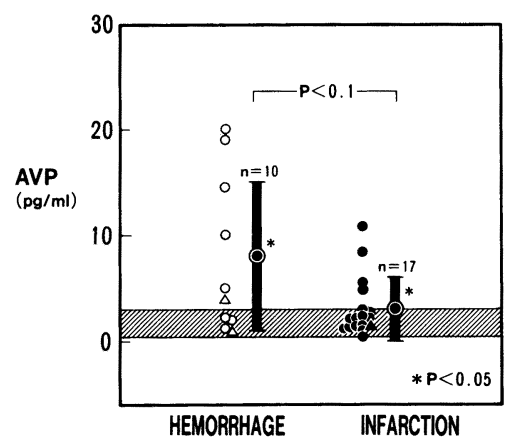

图1安静仰臥位に括ける血浆バジプレッシン (AVP)：脳出血群・脳梗塞群ともに健常者群に比し 有意に高値を示し, 脳出血群は脳梗塞群に比し高値 傾向を認めた。 各群の circle はテント上病变を, triangle は小脳病変を示し, 斜線部分は健常者群の mean $\pm 2 \mathrm{SD}$ を表す。

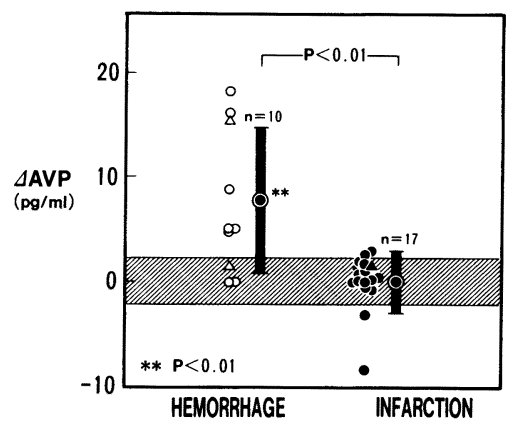

图 2 起立負荷に対する血浆バゾプレッシン ( $\triangle \mathrm{AVP})$ の変化: 脳出血群は脳梗塞群・健常者群に 比し有意の増加を認めた。

者群 $0.17 \pm 0.08 \mathrm{ng} / \mathrm{m} l$ と, 脳出血群は他の 2 群に比較 し高值傾向（p<0.1）を示した（表 1$).$

\section{（II] 起立負荷}

起立15分後において, 脳出血群の血浆 AVP 変化量 $(\Delta \mathrm{AVP})$ は $+7.7 \pm 6.9 \mathrm{pg} / \mathrm{m} l$ と有意に $(\mathrm{p}<0.05)$ 増 加し, 脳梗塞群および健常者群ではそれぞれ+0.2士 $2.6 \mathrm{pg} / \mathrm{m} l,+0.2 \pm 1.2 \mathrm{pg} / \mathrm{m} l$ とほぼ不変であった（表 1). 脳出血群はこれらいずれの群に比しても $1 \%$ 末 満の危険率で有意に反応性増加が大であった（図 2 ）。 また，起立試験における起立性収縮期血圧下降幅は， 脳出血群が健常者群に比し有意に大であったが，脳梗 塞群との間には有意な差を認めなかった(表 1).ささら に, 起立負荷前後において, 各群とも血清浸透圧の有 意な変化は見られなかった（表 1 ）。血㓡 $\mathrm{NE}$ の増加 $(\Delta \mathrm{NE})$ は脳出血群で $+0.21 \pm 0.18 \mathrm{ng} / \mathrm{ml}$ と他の 2 群

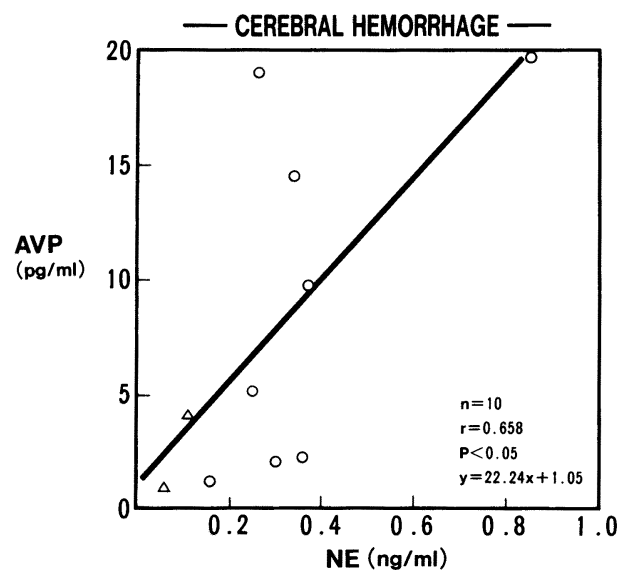

図 3 脳出血群の安静仰臥位における血浆バゾプレッ シン $(\mathrm{AVP})$ と血浆ノルェピネフリン $(\mathrm{NE})$ の関係： 脳出血群に打いて血浆 AVP と血浆 NE は有意の正 相関を示した.

に比べ高値傾向を示した（表 1 ）.

〔III〕血将 AVP と血将 NE, 血圧の関係

脳出血群に抢いて, 安静仰臥位の血浆 AVP は, 交感 神経遠心路機能を反映するとされる血浆 NEとの間 に有意な $(\mathrm{p}<0.05)$ 正相関を示した（図 3$)$. しかし， 脳梗塞群および健常者群では両パラメータ一間に有意 な相関を認めなかった。また，いずれの群においても 安静仰臥位時の血圧と血㓡 AVP, 起立性血圧下降の 程度と起立による血浆 AVP の变化の間に有意な相関 は認めなかった。

\section{〔IV〕血浆 AVP の経時的変化}

脳出血群に抒いて, 安静仰臥位 AVP おょび起立に よる AVP の増加の程度は発症早期に高値を示し, 時 間経過とともに双曲線を描いて低下した（図 $4 \mathrm{~A}, \mathrm{p}<$ 0.01 ; 図 $5 \mathrm{~A}, \mathrm{p}<0.05)$. 乙かし, 脳梗塞群では両パラ メーターともに経時的変化に何らかの関係も見出せな かった（図 4B，5B）。

\section{考察}

急性期脳血管障害患者に扮ける心・血管性自律神経 反射を検討した従来の成績(1) 3)101の中で，起立負荷に 対する血浆 AVP の変化を指標として用い, 圧受容器 を含む求心路の機能に焦点をあて検討した報告は，著 者が調べた限り見当たらず本成績が唯一の報告と思わ れる。

今回の成績のうち, まず安静仰臥位の血浆 AVP は 脳出血群および脳梗塞群ともに対照群に比し有意の高 


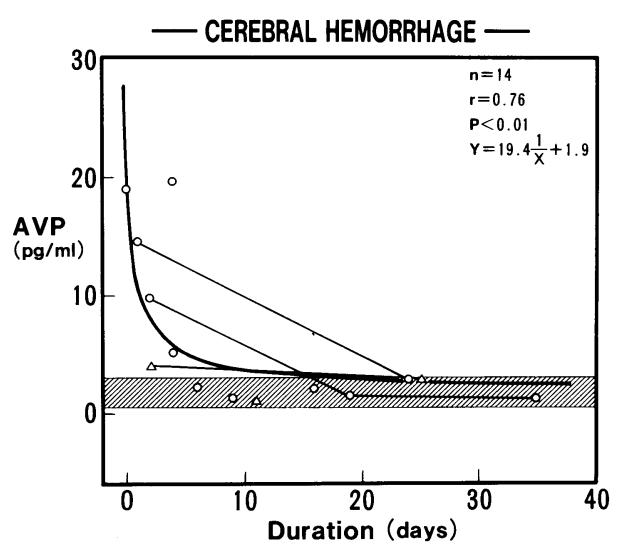

A

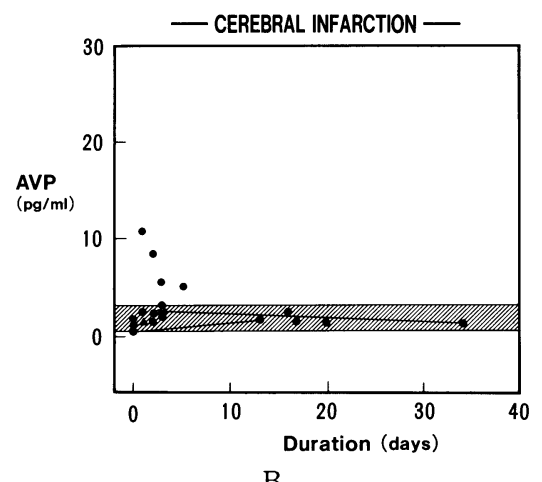

B

図 4 脳出血群および脳梗塞群の安静仰臥位における 血浆バゾプレッシン (AVP) の経時的変化：脳出血 群 (A) では，血浆 AVP は発症早期に高值を示した 後, 時間経過とともに双曲線を描いて速やかに低下 した $(\mathrm{p}<0.01)$. ○はテント上病変を, $\triangle$ は小脳病 変を示す。脳梗塞群 (B) では明らかな傾向は見られ なかった， はテント上病変を，、は小脳病変を示 し, 斜線部分は健常者群の mean $\pm 2 \mathrm{SD}$ を表す。

值を示し,さらに前者の血浆 AVP は後者に比べ高値 傾向を認めた（図 1)。これまでの報告の中で, 宮坂 $5^{4)}$, S $\phi$ rensen $5^{11)}$ の成績は著者と同様に, 血浆 AVP が脳出血群で健常者群に比し有意に高值を示してい る。一方, 脳梗塞群では有意の増加は認めず, 著者ら の結果とは異なっている. Joynt $ら^{12)}$ は脳梗塞群およ びくも膜下出血群の両群ともに，有意の高值を示した 成績を報告している。森永ら9は脳血管障害超急性期 （発症 3 日以内）には血浆 AVP が著増した成績を得て いる。また，Olsson ら ${ }^{13)}$ とよると血浆 AVPは一過性 脳虚血発作群>脳梗塞群>脳出血群の順に高値を示し たと報告しているが，一過性脳虚血発作 4 例，脳梗塞

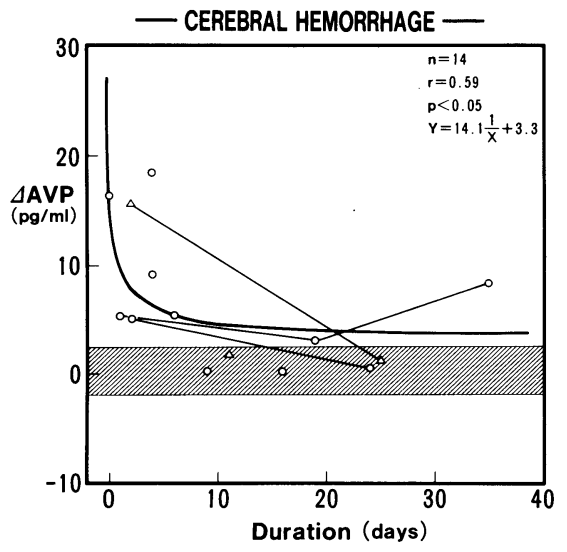

A

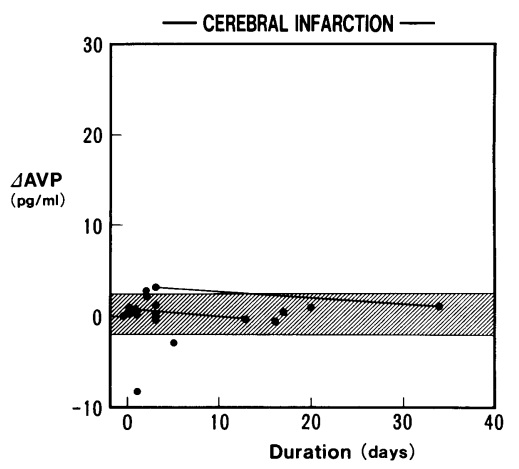

B

図 5 脳出血群および脳梗塞群の起立負荷に対する血 浆バゾプレッシン $(\Delta \mathrm{AVP})$ 変化量の経時的変化： 脳出血群 (A) では, 起立による血浆 AVP の増加が 発症早期に認められ，時間経過とともに双曲線を描 いて速やかに低下した $(\mathrm{p}<0.05)$. 脳梗塞群 (B) で は明らかな傾向は見られなかった。

10例, 脳出血 2 例と脳梗塞群を除き症例数が少ないこ と，発症から検査までの期間に関する記載がないため 比較は困難である。

従来, 脳梗塞および脳出血患者について安静仰臥位 の血浆 AVP を測定した報告は，主にSIADH との関 連で検討されてきた(4)12114)。 その他には脳血管障害以 外の神経疾患 ${ }^{11) 13)}$, 健常者 ${ }^{11)}$ との比較に打いて安静仰 臥位の血浆および髄液 AVP が検討されているのが中 心である。これらの報告では, 脳血管障害患者の安静 仰臥位における血浆 AVP は，血浆浸透圧から予測さ れる範囲を越えて増加しており，その発現機序として 非浸透圧性因子の関与が示唆される49912)14).

脳血管障害を含む中枢神経疾患における血浆 AVP 上昇の発現機序は, (1)圧受容器からの抑制線維の障害 
がAVP 分泌細胞の脱抑制を招来して血浆 AVPの増 加をもたらす ${ }^{12)}$ ，(2)頭蓋内圧方進が AVP 分泌を促進 する(15)16)，(3)神経細胞の破壊により AVP が脳組織か ら血中へ漏出する ${ }^{17) 18)}$ ，(4)病巣からの直接あるいは間 接的刺激が AVP 分泌細胞に働く ${ }^{191}$ 21)，などの説が主 張されている. (1)の説に関しては後述するように，圧 受容器求心路機能が保たれていると考兄られることか ら否定的である。 また，(2)の頭蓋内圧六進説について も以下の理由で受け入れ難い。すなわち, 脳血管障害 患者に打ける頭蓋内圧方進のピークは発症直後より遅 れて出現するが22), 本研究では脳出血患者の血浆 AVP のピークは発症早期に認められたことから，血浆 AVP 上昇の主な原因とは考学難い（図 4A).ささらに, 頭蓋内圧元進は血浆 AVP と相関が認められなかった 成績も報告されている ${ }^{23)}$. (3), (4)の機序は脳血管障害に おいて当然起こりらるものと考兄られ，血浆 AVP 分 泌促進の病態を修飾している可能性があると思われ る.

AVPの分泌に対する非浸透圧刺激の一つとして起 立負荷があげられる ${ }^{8)}$. 容量受容器および圧受容器か らの求心線維はともに延髄の孤束核に入り, 直接ある いは A1，A2拈よび A6領域を経て，noradrenergic 線 維が視床下部の視索上核および室傍核に投射してい $ろ^{5)}$. とくに圧受容器からの入力は主に背側 noradrenergic bundle が関与しているといら ${ }^{24)}$. 全身血圧 上昇時には圧受容器の興奮が高まり, AVP 分泌細胞 を含む視索上核および室榜核に対して抑制性に作用 し, AVPの分泌は低下する。逆に, 起立負荷時には静 脈還流量の減少, 全身血圧の低下により容量受容器お よび圧受容器の興奮が減弱し, AVPの分泌は促進さ れる6). したがって, 起立負荷による血浆 AVP の変化 量は, 細胞外液浸透圧および循環血浆量に変化を認め ないとき, 圧受容器求心路の機能を示しているものと 考えられる7).

本研究では, 起立負荷に対する血浆 AVP の増加は 脳出血群において, 健常者群のみならず脳梗塞群に比 し有意に大であった(図 2 )。しかも, 脳出血群におい て, 血浆 AVP の起立による増加の程度が経過に伴っ て速やかに低下した成績は（図 5A)，起立負荷に対す る血浆 AVP の分泌過剩が脳出血の結果として生じた ものであることを強く示唆している。

脳血管障害では脳組織内の NEが減少するといわ れているが25), AVP 分泌に対するNEが及ぼす影響 に関しては, 従来, NEはAVP 分泌を抑制する ${ }^{26)}$, 逆
にAVP 分泌を促進する27)，などその結論は一致して いない，前者の立場に立てば，脳血管障害では脳内の NEが減少し，NEによるAVP 分泌抑制は少なくな り，その結果 AVP は増加するものと考兄られる。亦 た, 後者の説をとれば脳内 NEが減少し, NEの AVP 分泌促進は障害されることになり，本研究の成績とは 矛盾する。、ずれにしてもAVP増加が起立負荷に対 して正常以上の反応を示したことから脳幹内求心路の 遮断によるものであるとは考朰にくい.

なぜ, 脳出血群に执いてのみ起立負荷で血浆 AVP が増加したのか本研究のみからは明らかではないが, 脳出血群の起立性血圧下降の程度が健常者群に比し有 意に大であり，その結果として血浆 AVP の分泌が反 応性に增加した可能性も否定できない。しかし, 起立 性血圧下降の程度とそれに対応する血浆 AVP の増加 の程度との間に相関関係は認められず，この立場のみ からの説明は困難と考えられる.

脳出血では脳梗塞とは異なったニューロトランス ミッターの擾乱が生じ, 加光て両群における脳虚血の 程度およびその質が異なっているものと推測され，脳 出血に打いては起立負荷により血浆 AVP の過䛢な増 加が認められ, 少なくとも圧受容器求心路の機能低下 はないものと考觉られる。

また，安静仰臥位の血浆 AVP および NEの間に有 意の相関関係がみられたことより (図 3 ), 圧受容器求 心路は交感神経遠心路からも少なからず影響を受けて いることが示唆された。

以上, 脳血管障害患者の予後に自律神経障害, SIADH はともに重大な影響を与える因子であり，こ れらの病態の認識が脳血管障害の急性期治療を実施す る上で重要である。これらを踏をえ本症における AVP 動態をさらに多角的に検討する必要があると考 える.

擱筆に際し御指導・御校閲を賜った濱口勝彦教授, 直接御 指導を賜った島津邦男助教授, 田村直俊博士に深謝いたし ます。また, 御協力戴いた金 浩澤, 山元敏正の各博士, 中 村安孝氏に謝意を表します。

本論文の要旨は, 第30回日本老年医学会総会（1988年 9 月，長崎）において発表した。

\section{文献}

1）島津邦男, 後藤文男, 小松本悟：脳血管障害と自律 神経機能. 自律神経 15:193-199, 1978

2) 田村直俊：半球性脳血管障害における副交感およ 
び交感神経機能. 臨床神経 $23: 787-795,1983$

3）大岩海陽：半球性脳血管障害における脳循環自動 調節の経時的変化と副交感神経機能の関連. 脳卒 中 $7: 1-8,1985$

4）宮坂佳男, 常磐嘉一, 別府俊男ら：高血圧性脳出血 および脳梗塞例における $\mathrm{ADH}$ 分泌異常症候群。 Neurol Med Chir (Tokyo) 26: 284-290, 1986

5) Sawchenko PE, Swanson LW: The organization of noradrenergic pathways from the brainstem to the paraventricular and supraoptic nuclei in the rat. Brain Res Rev $4: 275-325$, 1982

6) Share L: Blood pressure, blood volume, and the release of vasopressin. In Knobil E, Sawyer WH (eds) : Handbook of Physiology, Sect 7, vol IV, part 1, Washington DC, American Physiological Society, 1974, pp243-255

7) Zerbe RL, Henry DP, Robertson GL: Vasopressin response to orthostatic hypotension. Etiologic and clinical implications. Am J Med $74: 265-271,1983$

8）桜井兵一郎, 栗本文彦, 大野英人ら：逆相 $\mathrm{C}_{18}$ シリ カカラムを用いた高感度 Radioimmunoassay に よる血浆 8-arginine vasopressin の測定法. 日内 分泌会誌 $61: 724-736,1985$

9）森永一生, 松岡高博, 松本行弘ら：脳血管障害急性 期に認められる低 $\mathrm{Na}$ 血症の発生機序. Neurol Med Chir (Tokyo) 27 : 1046-1052, 1987

10）後藤文男：脳血管障害の病態生理. 脳卒中 $2: 64$ $-73,1980$

11) $\mathrm{S} \phi$ rensen PS, Gjerris A, Hammer $M$ : Cerebrospinal fluid vasopressin in neurological and psychiatric disorders. J Neurol Neurosurg Psychiatry $48: 50-57,1985$

12) Joynt RJ, Feibel JH, Sladek CM : Antidiuretic hormone levels in stroke patients. Ann Neurol 9: 182-184, 1981

13) Olsson J, Forsling ML, Lindvall B, et al : Cerebrospinal fluid arginine vasopressin in Parkinson's disease, dementia and other degenerative disorders. In Yahr MD, Bergman KJ (eds) : Adv Neurol 45, New York, Raven Press, 1986, pp239-242

14) Lee $T$, Hsieh B, Huang G: Syndrome of inappropriate secretion of antidiuretic hormone in stroke patients. J Formosan Med Assoc 83 :
640-645, 1984

15) Gaufin L, Skowsky R, Goodman SJ : Release of antidiuretic hormone during mass-induced elevation of intracranial pressure. J Neurosurg 46 : 627-637, 1977

16) Rap ZM, Chwalbinska-Moneta J : Vasopressin concentration in the blood during acute shortterm intracranial hypertension in cats. In Cervos-Navarro, et al (eds): Adv Neurol 20, New York, Raven Press, 1978, pp381-388

17) Perlroth MG, Tschudy DP, Marver HS, et al : Acute intermittent porphyria. New morphologic and biochemical findings. Am J Med $41: 149-162,1966$

18) Stein JA, Curl FD, Valsamis M, et al : Abnormal iron water metabolism in acute intermittent porphyria with new morphologic findings. Am J Med 53 : 784-789, 1972

19) Hayward JN, Smith WK : Influence of limbic system on neurohypophysis. Arch Neurol $9: 171$ $-177,1963$

20) Rovit RL, Sigler MH : Hyponatremia with herpes simplex encephalitis. Possible relationship of limbic lesions and ADH secretion. Arch Neurol 10 : 595-603, 1964

21) Becker RM, Daniel RK: Increased antidiuretic hormone production after trauma to the craniofacial complex. J Trauma 13 : 112-115, 1973

22）田澤俊明, 水上公宏 : 脳出血と頭蓋内圧. 後藤文男 (編)：頭蓋内圧と脳浮腫. 東京, 中外製薬 (株), 1983, pp269-278

23) S $\phi$ rensen PS, Gjerris F, Hammer M: Cerebrospinal fluid vasoressin and increased intracranial pressure. Ann Neurol 15 : 435-440, 1984

24) Lightman SL, Todd K, Everitt BJ : Ascending noradrenergic projections from the brainstem: Evidence for a major role in the regulation of blood pressure and vasopressin secretion. Exp Brain Res 55 : 145-151, 1984

25）田中耕太郎：脳血管障害と神経伝達物質. 後藤文 男, 萬年 徹, 高倉公明ら (編): Annual Review 神経 1989, 東京, 中外医学社, 1989, pp118-140

26) Armstrong WE, Sladek CD, Sladek JR: Characterization of noradrenergic control of vasopressin release by the organ-cultured rat 
hypothalamo-neurohypophyseal system. Endocrinology $111: 273-279,1982$

27) Miller TR, Handelman WA, Arnold PE, et al : Effect of central catecholamine depletion on the osmotic and nonosmotic stimulation of vasopressin (antidiuretic hormone) in the rat. J Clin Invest $64: 1599-1607,1979$

\title{
Abstract \\ Response of plasma arginine vasopressin to orthostatic change of blood pressure in acute cerebrovascular diseases
}

\author{
Seietsu Watanabe, M.D.
}

Department of Neuroloy, Saitama Medical School

Evidence has been accumulated that patients with acute cerebrovascular diseases (CVD) are attended with disturbances of autonomic nervous functions. The response of plasma arginine vasopressin (AVP) to postural change had been regarded as an index of the function in the autonomic afferent division from baroreceptors and volume recepotrs. The present study was designed to investigate the autonomic afferent nervous function in the patients with acute CVD.

The test of $70^{\circ}$ passive head-up tilting for 15 minutes was performed on 27 patients ( $64 \pm 11$ y.o.; mean \pm S.D. with acute (5.0 \pm 5.9 days after the onset) CVD [10 with intracerebral hemorrhages (ICH), 17 with cerebral infarctions (CI)] and 13 age-matched healthy volunteers as controls. The blood was sampled before and during head-up tilting in order to measure plasma AVP and norepinephrine (NE).

[1] Supine position: The plasma AVP significantly increased in both ICH and CI as compared to the controls $(\mathrm{p}<0.05, \mathrm{p}<0.05$, respectively). It tended to be higher in the group with ICH than in the group with $\mathrm{CI}(\mathrm{p}<0.1)$. There was a positive correlation between plasma level of AVP and NE ( $p<0.05)$. [2] Head-up position: 1) The significantly greater rise in AVP $(\triangle \mathrm{AVP})$ to postural change was observed in ICH as compared to $\mathrm{CI}$ and the controls $(\mathrm{p}<0.01$, $\mathrm{p}<0.01) .2)$ The increase in NE tended to be greater in ICH than in IC or in the controls $(\mathrm{p}<0.1)$.

This study provides strong evidence that exaggerated responses occur not only in the efferent division but in the afferent division of the autonomic reflex arch in the acute intracerebral hemorrhage.

(Jpn. J. Stroke 12: 51-57, 1990) 